\title{
Annual effects of different organic fertilisers in a baby leaf crops system under tunnel in Southern Italy
}

\author{
Luigi Morra, Maurizio Bilotto, Salvatore Baiano, Giovanni Saviello, Domenico Cerrato \\ Unità di Ricerca per la Frutticoltura, Consiglio per la Ricerca in Agricoltura e l'Analisi \\ dell'Economia Agraria, Caserta, Italy
}

\begin{abstract}
In a farm devoted to the production of fresh-cut leafy vegetables located in Eboli (Salerno), it was carried out a trial to compare the effects on crops and soil organic carbon (SOC) of biowaste compost, olive pomace compost, buffalo manure applied to soil in two doses (15 and $30 \mathrm{t} \mathrm{ha}^{-1}$ fresh weight). The amendments were tested in order to start in defining a feasible strategy for the recovery/maintenance of soils in degradation due to the organic matter depletion triggered by the intensive soil tillage and the lack of organic matter returned to soil. In the year following the soil amendment, it was studied the crop sequence: rocket-basil-rocket. Analysis of nitrates concentration in leaves of rocket was carried out on samples of all the treatments picked up in the two cycles of rocket. Along the year, we observed that the higher yields promoted in the first six months (May-September) from the dose $15 \mathrm{t} \mathrm{ha}^{-1}$, were obtained with the dose $30 \mathrm{t} \mathrm{ha}^{-1}$ in the successive six months (November-May). This was due, probably, to the larger stock of total $\mathrm{N}$ supplied with dose 30 and its release in time. Buffalo manure amendment showed a higher quickness than com-
\end{abstract}

Correspondence: Luigi Morra, Unità di Ricerca per la Frutticoltura, Consiglio per la Ricerca in Agricoltura e l'Analisi dell'Economia Agraria, via Torrino 3, 81100 Caserta, Italy.

Tel.: +39.0823.256213.

E-mail: luigi.morra@entecra.it

Key words: Biowaste compost; buffalo manure; olive pomace compost; soil organic carbon balance; rocket; leaf nitrate content.

Funding: the research was funded by Campania Region, Assessorato Agricoltura - Project Centro Orticolo Campano.

Acknowledgements: the authors would like to thank Mrs A. Carella for the laboratory analysis of nitrate concentration in rocket leaves.

Conference presentation: SIA XLIII Congress, Pisa, 2014.

Received for publication: 2 December 2014.

Revision received: 25 May 2015.

Accepted for publication: 26 May 2015.

(C) Copyright L. Morra et al., 2015

Licensee PAGEPress, Italy

Italian Journal of Agronomy 2015; 10:642

doi:10.4081/ija.2015.642

This article is distributed under the terms of the Creative Commons Attribution Noncommercial License (by-nc 3.0) which permits any noncommercial use, distribution, and reproduction in any medium, provided the original author(s) and source are credited. posts in the supplying mineral nitrogen to the first crops. On the other hand, nitrates in leaves of rocket exceeded, more frequently, the limits fixed in EU Regulation n. 1258/2011 in the plots amended with buffalo manure. Instead, the treatments with olive pomace compost showed to exceed rarely the EU limits. Under tunnel, the intensive management based on 4-5 crop cycles per year and as much soil tillage, appeared the first cause to explain the lack of significant variation in SOC of plots treated with organic improvers after one year from their distribution. This result let us to suppose the need to study some modifications of the standard farm management in order to reduce the number of soil tillage in a year and, as a consequence, the main stress causing the high carbon mineralisation rate in soil under tunnel.

\section{Introduction}

The cultivation of the fresh-cut leafy vegetables as the raw material for the agro-industry sector devoted to the production of the ready-toeat fresh vegetables, has experienced a strong growth over the past 15 years in Italy. Pimpini et al. (2005) reported the main area of cultivation was in Campania (Sele river Plain, south to Salerno) with 1550 hectares, while the areas of initial spread of this sector, in Lombardia, Veneto, Friuli Venezia Giulia, Piemonte and Emilia Romagna followed at a distance with $402,399,132,65,40$ hectares, respectively. In 2013, the market of the ready-to-eat vegetables was estimated to have a turnover of $€ 720$ millions (Franceschini, 2014). In the Sele river Plain the area devoted to the fresh-cut leafy vegetable has spread further to the current 3600 hectares of crops under tunnels. The most cultivated species are: rocket (Diplotaxis tenuifolia DC.) on $50 \%$ of surfaces, lettuce (Lactuca sativa L.) on 20\%, spinach and beet (Spinacia oleracea L. and Beta vulgaris L. var. cycla) on $20 \%$, other crops on $10 \%$. The turnover has estimated around $€ 216-290$ millions (Del Grosso M., 2014, personal communication). Bonanomi et al. (2011) carried out a study precisely in the Sele River Plain with the aim to assess the longterm impact of intensive cultivation under permanent plastic tunnel on soil quality. The results indicated that long-lasting soil cultivation under plastic cover negatively affects soil carbon (C) content, microbial biomass, soil enzymatic activities, functional and species diversity and soil salinity.

The fresh-cut leafy vegetables are produced in specialised farms that are equipped with plastic tunnels and suitable mechanical equipment, as well as plants of pre-washing and refrigeration products. Compared to the conventional cropping systems in greenhouses, based on 2-3 crop cycles per year, the production of leafy vegetables increased the crop intensification in terms of number of crop cycles (5-7 per year), number of harvests/cuts (around 10 cuts per year), number of soil tilling per year (Penati et al., 2009). As a consequence, the combined effects of repeated soil tillage, optimal temperature and water content by localised irrigation under greenhouse promote an increase in the mineralisation rate of soil organic matter and the 
reduction of soil organic $\mathrm{C}$ content. Strictly linked to this decay is the decline in soil structure, a form of soil degradation. Soil structure influences soil water movement and retention, erosion, crusting, nutrient recycling, root penetration and crop yield (Bronick and Lal, 2005). Therefore a more sustainable management of the fresh-cut leafy vegetables sector represents a mandatory challenge if we have to go towards a sustainable intensification of the crop systems that guarantee simultaneously the improving of the productivity and of the environmental management of agricultural land (Buckwell et al., 2014).

Until now, the main topic of the literature about the fresh-cut leafy vegetables focused, on one hand, on the effects of cultural practices on yield and produce quality regardless its final destination. On the other hand, it focused on the effect of processing conditions on raw material whose production system is often unknown (Nicola and Fontana, 2007; Fontana et al., 2010). In both the cases it is difficult to find studies that deepen the effects of these very intensive crop systems on the quality of soil or groundwater.

The exploitation of organic amendments for baby leaf crops that are in direct contact with the soil, gives rise to many suspicions by large food retailers about the possibility that the organic improvers be complying with good agricultural practices indispensable to prevent plant food contamination by foodborne pathogens. Selma et al. (2010), Suslow et al. (2003) pointed out the risks of faecal microorganisms contamination deriving from the use of not stabilised and mature materials such as sewage sludge or fresh manure.

Penati et al. (2009) carried out in Lombardia, under tunnel devoted to fresh-cut leafy vegetables, an articulated research in order to determine the amount of nitrogen (N) uptake by lettuce, rocket, endive, and spinach. Knowledge of these data is fundamental to correctly scheduling mineral fertilisation on the basis of the Balance sheet method taking into account input and output. Besides, nitrogen fertilisation is known to be among the main factors influencing the nitrate content in vegetables (Martinetti, 1996; Paradiso et al., 2001; Parente et al., 2002; Santamaria et al., 2002). Among leafy vegetables, rocket is considered to be a hyper-accumulator of nitrates as it contains the highest amount of nitrates. Rocket can overcome the amount of $9000 \mathrm{mg} \mathrm{kg}^{-1}$ of fresh weight in different period of the year and in different growing systems (Santamaria, 2006; Cavaiuolo and Ferrante 2014). Bearing in mind that vegetables are the main source of nitrate intake in the human diet (70-94\%), legal limits to nitrate contents are imposed from EU.
Nowadays, the European Commission (2011) published Regulation $\mathrm{n}$. 1258/2011 that fixed maximum concentrations of nitrates in food. In particular, with regard to the rocket, there are two limits: $7000 \mathrm{mg} \mathrm{kg}^{-1}$ of fresh matter for produce harvested from the $1^{\text {st }}$ of October to 31 March, $6000 \mathrm{mg} \mathrm{kg}^{-1}$ of fresh matter for produce harvested from the $1^{\text {st }}$ of April to 30 September.

The objectives of the present study carried out in a private farm devoted to leafy vegetables production, were: i) to assess the effect on the soil organic $\mathrm{C}$ balance of different organic improvers (olive pomace compost, biowaste compost, cow manure) distributed according to the doses of 15 and $30 \mathrm{t} \mathrm{ha}^{-1}$ of fresh matter; ii) to evaluate the ability of organic fertilisers, minimally or not integrated by mineral ones, of sustain the nutrition of crops in a year long; iii) to measure the nitrate content in rocket leaves as influenced by organic improvers.

\section{Materials and methods}

\section{Treatments and experimental design}

Four organic fertilisers characterised by different chemical-physical parameters were tested (Table 1). They were: i) olive pomace compost with low $\mathrm{C} / \mathrm{N}$ ratio produced with three phases olive oil mill wastes mixed to wooden chips (OPComL); ii) olive pomace compost with high $\mathrm{C} / \mathrm{N}$ ratio produced with three phases olive oil mill wastes mixed to wooden chips and wastes from production of sheep wool as $\mathrm{N}$ source (OPComH); iii) biowaste compost produced with the organic fraction separately collected from the municipal solid waste (BWCom); iv) buffalo manure aged 5 months and supplied from a livestock farm nearby the research area (BM). The first two composts were supplied by the composting plant of the Centro Sperimentale di Compostaggio (CESCO) in Laurino (SA, Italy) managed by the National Park of Cilento and Vallo di Diano while the biowaste compost was supplied by the composting plant of the city of Salerno. The Table 1 shows the main chemical characteristics of the composts and the manure. The two olive pomace composts differ between them only in the total $\mathrm{N}$ content and, consequently in $\mathrm{C} / \mathrm{N}$ ratio, which is 11 in $\mathrm{OPComL}$ and 30 in $\mathrm{OPComH}$; their organic $\mathrm{C}$ content is similar to $\mathrm{BM}$ and higher than BWCom. The dry matter content of composts, as expected, was higher than that of buffalo manure.

Table 1. Chemical parameters characterising the organic fertilisers tested in the trial.

\begin{tabular}{|c|c|c|c|c|c|c|}
\hline Parameter & Unit & OPComL & OPComH & BWCom & BM & Limits D.Lgs. 75/10 \\
\hline Umidity & $\%$ & 24 & 25.7 & 11 & 61 & 50 \\
\hline $\mathrm{pH}$ & & 8.5 & 6.9 & 7.6 & - & $6-8.5$ \\
\hline Total N & \% d.m. & 3.18 & 1.25 & 1.65 & 2.5 & - \\
\hline Organic N & $\% \mathrm{~N}$ tot & 97.8 & 99.8 & 82.4 & - & $>80$ \\
\hline Total organic carbon & $\%$ d.m. & 36.7 & 38.3 & 26.4 & 38.5 & $>20$ \\
\hline Humic + fulvic acids & $\%$ d.m. & 11.2 & 12.7 & 7.7 & - & $>7$ \\
\hline $\mathrm{C} / \mathrm{N}$ & & 11.5 & 30.6 & 16 & 15.4 & $\max 25-50^{*}$ \\
\hline Cadmium & $\mathrm{mg} \mathrm{kg}^{-1}$ d.m. & $<0.5$ & $<0.5$ & $<0.5$ & - & 1.5 \\
\hline Chrome $^{6+}$ & $m g \mathrm{~kg}^{-1}$ d.m. & $<0.5$ & $<0.5$ & $<0.1$ & - & 0.5 \\
\hline Mercury & $\mathrm{mg} \mathrm{kg}^{-1}$ d.m. & $<0.2$ & $<0.2$ & $<0.5$ & - & 1.5 \\
\hline Nickel & $\mathrm{mg} \mathrm{kg}^{-1}$ d.m. & 3.0 & 3.8 & 4.8 & - & 100 \\
\hline Lead & $\mathrm{mg} \mathrm{kg}^{-1}$ d.m. & 2.9 & 2.1 & 21.3 & - & 140 \\
\hline Copper & $m g \mathrm{~kg}^{-1}$ d.m. & 16.4 & 16.8 & 52.3 & - & 230 \\
\hline Zinc & $\mathrm{mg} \mathrm{kg}^{-1}$ d.m. & 46.5 & 33.1 & 164 & - & 500 \\
\hline
\end{tabular}

OPComL, olive pomace compost with low carbon/nitrogen (C/N) ratio; OPComH, olive pomace compost with high C/N; BWCom, municipal source separated organic fraction compost; BM, buffalo manure. 
The organic fertilisers were distributed in soil on April $28^{\text {th }}, 2013$; the amounts applied for each organic improver were 15 and $30 \mathrm{t} \mathrm{ha}^{-1}$ as fresh matter. So, eight treatments plus a treatment control (CNT) were compared according to a randomised complete block design with three replicates. The CNT treatment was fertilised only with mineral fertilisers via fertigation. Each organic fertiliser was hand-distributed on the experimental units constituted by the raised beds where are seeded the baby leaf crops. Each plot measured $1.6 \times 15 \mathrm{~m}$. In the Table 2 were compared the amounts of dry matter, total, organic and mineral $\mathrm{N}$, total organic C (TOC) corresponding to each dose of organic fertiliser tested. The amounts of dry matter and TOC in the composts were approximately twice the manure whereas total $\mathrm{N}$ content in the composts was over $90 \%$ formed by organic $\mathrm{N}$.

\section{Experimental site and crop system management}

The trial was hosted in a farm associated to the Cooperative Terramore in the Sele river Plain, Eboli, largely devoted to the production of baby leaf crops such as rocket, salad, endive, basil. The baby leaf crops are produced under multiple tunnels with a cubic capacity higher than $3 \mathrm{~m}^{3}$ per $\mathrm{m}^{2}$, covered with plastic film, not heated. Each tunnel measured $32.5 \times 7.5 \mathrm{~m}$. The soil under tunnel had a sandy-clay texture with clay $360 \mathrm{~g} \mathrm{~kg}^{-1}$, sand $520 \mathrm{~g} \mathrm{~kg}^{-1}$, silt $120 \mathrm{~g} \mathrm{~kg}^{-1} ; \mathrm{pH} 8.2$, electrical conductivity $1.38 \mathrm{dS} \mathrm{m}^{-1}$, soil organic carbon content $5.4 \mathrm{~g} \mathrm{~kg}^{-1}(0.9 \%$ as organic matter), total $\mathrm{N} 0.62 \mathrm{~g} \mathrm{~kg}^{-1}, \mathrm{C} / \mathrm{N} 8.7, \mathrm{P}_{2} \mathrm{O}_{5} 19 \mathrm{mg} \mathrm{kg}^{-1}, \mathrm{~K}_{2} \mathrm{O}$ $210 \mathrm{mg} \mathrm{kg}^{-1}$. Crops are irrigated through sprinklers located $2.5 \mathrm{~m}$ above the soil. After the seeding, soil is irrigated $1.5 \mathrm{~h}$, once in the autumnwinter cycle of rocket, repeatedly for 15 ' a day until germination during the spring-summer cycles of rocket or basil. Every crop is irrigated the day before each cutting for 15'. After each cut, a fertigation follows for 30 '-1 h.

In Table 3 is summarised the main information about the crop cycles carried out. It is worth to note the high intensity of soil tillage every time a new crop has to be seeded.

\section{Samplings and laboratory analysis}

Crop yields were estimated by harvesting on two sampling areas in each plot. Precisely, we cut the baby leaves (10-15 cm high) insight a $0.25 \mathrm{~m}^{2}$ square in order to determine fresh biomass. The number of cuts per crop cycle is showed in Table 3 . The calculation of yields per hectare took in account the area actually sown net of roadways $(=0.84)$.

The influence of the organic improvers on the accumulation of nitrates in the leaves of rocket was evaluated by measuring their contents in samples coming from different cuts of the first and the second cycle. The first cycle took place when the limit of concentration fixed by EU Reg. 1258/2011 is $6000 \mathrm{mg} \mathrm{kg}{ }^{-1}$ fresh matter (f.m.) (European Commission, 2011). In the second cycle of rocket, the EU nitrate limit is $7000 \mathrm{mg} \mathrm{kg}^{-1}$ fresh weight (f.w.). In order to measure the nitrate content in leaves of rocket, samplings harvested always in the same hours (10-12 a.m.) were frozen. We sampled on June $4^{\text {th }}, 11^{\text {th }}$ and $17^{\text {th }}$ 2013 in the spring cycle of rocket and three times in the autumn-spring

Table 2. Fresh matter and corresponding dry matter, organic carbon, total, organic and mineral nitrogen applied with the different organic amendants.

\begin{tabular}{|c|c|c|c|c|c|c|}
\hline Organic amendants & $\begin{array}{c}\text { Fresh matter } \\
\qquad \mathrm{tha}^{-1}\end{array}$ & $\begin{array}{l}\text { Dry matter } \\
\qquad \mathrm{tha}^{-1}\end{array}$ & $\begin{array}{l}\text { C org } \\
\mathrm{t} \mathrm{ha}^{-1}\end{array}$ & $\begin{array}{c}\mathrm{N} \text { tot } \\
\mathrm{kg} \mathrm{ha}^{-1}\end{array}$ & $\begin{array}{c}\text { Norg } \\
\mathrm{kg} \mathrm{ha}^{-1}\end{array}$ & $\begin{array}{l}\text { Nmin } \\
\mathrm{kg} \mathrm{ha}^{-1}\end{array}$ \\
\hline OPComL & 15 & 11 & 4.2 & 363 & 355 & 8 \\
\hline OPComL & 30 & 23 & 8.4 & 725 & 709 & 16 \\
\hline OPComH & 15 & 11 & 4.2 & 139 & 138 & 1 \\
\hline OPComH & 30 & 22 & 8.5 & 278 & 275 & 3 \\
\hline BWCom & 15 & 13 & 3.5 & 219 & 181 & 39 \\
\hline BWCom & 30 & 27 & 7.0 & 441 & 363 & 77 \\
\hline BM & 15 & 6 & 2.2 & 145 & - & - \\
\hline BM & 30 & 12 & 4.5 & 293 & - & - \\
\hline
\end{tabular}

OPComL, olive pomace compost with low carbon/nitrogen $(\mathrm{C} / \mathrm{N})$ ratio; OPComH, olive pomace compost with high $\mathrm{C} / \mathrm{N}$; BWCom, municipal source separated organic fraction compost; BM, buffalo manure.

Table 3. Main information about the crop system management applied along the year.

\begin{tabular}{|c|c|c|c|c|c|}
\hline Soil tillage & $\begin{array}{l}\text { Crop } \\
\text { sequence }\end{array}$ & $\begin{array}{l}\text { Date of seeding } \\
\text { and seed density }\end{array}$ & $\begin{array}{l}\text { Number } \\
\text { of cuts }\end{array}$ & $\begin{array}{l}\text { Mineral } \\
\text { fertilisation* }\end{array}$ & Last harvest \\
\hline $\begin{array}{l}\text { Chisel cultivation at } 50 \mathrm{~cm} \text { depth }+ \\
\text { rotovator cultivation at } 20 \mathrm{~cm}+ \\
\text { raised seedbed preparation }\end{array}$ & $\begin{array}{l}\text { Rocket (Diplotaxis } \\
\text { tenuifolia), cv. } \\
\text { Reset }\end{array}$ & $\begin{array}{l}\text { May 2, } 2013 \\
5.5 \mathrm{~kg} \mathrm{ha}^{-1}\end{array}$ & 3 & $\begin{array}{l}19-9.5-8.5 \mathrm{~kg} \mathrm{ha}^{-1} \text { of } \\
\mathrm{N}-\mathrm{MgO}-\mathrm{K}_{2} \mathrm{O} \text { respecitvely } \\
\text { with one application }\end{array}$ & June 17, 2013 \\
\hline $\begin{array}{l}\text { Rotovator cultivation at } 20 \mathrm{~cm}+ \\
\text { raised seedbed preparation }\end{array}$ & Rocket** & July & & & July \\
\hline $\begin{array}{l}\text { Rotovator cultivation at } 20 \mathrm{~cm}+ \\
\text { raised seedbed preparation }\end{array}$ & $\begin{array}{l}\text { Basil (Ocimum } \\
\text { basilicum), } \\
\text { cv. Compatto }\end{array}$ & $\begin{array}{l}\text { August 28, } 2013 \\
20 \mathrm{~kg} \mathrm{ha}^{-1}\end{array}$ & 2 & None & October 10, 2013 \\
\hline $\begin{array}{l}\text { Chisel cultivation at } 50 \mathrm{~cm} \text { depth }+ \\
\text { rotovator cultivation at } 20 \mathrm{~cm}+ \\
\text { raised seedbed preparation }\end{array}$ & $\begin{array}{l}\text { Rocket (Diplotaxis } \\
\text { tenuifolia), cv. } \\
\text { Winter }\end{array}$ & $\begin{array}{l}\text { November 7,2013 } \\
5 \mathrm{~kg} \mathrm{ha}^{-1}\end{array}$ & 7 & $\begin{array}{l}10 \mathrm{~kg} \mathrm{~N} \mathrm{ha}^{-1} \text { in one } \\
\text { application }\end{array}$ & May 8, 2014 \\
\hline
\end{tabular}

*Fertigations were executed in treatment control plots as well as in the amended ones; ${ }^{* *}$ crop not monitored. 
cycle (on February $14^{\text {th }}$, on March $28^{\text {th }}$, on April 14 ${ }^{\text {th }} 2014$ ). According to another European Commission Regulation (2006), after unfreezing, 50 $\mathrm{g}$ of leaves were homogenised, then juice were centrifuged 5 ' at 4500 rpm, supernatant removed, and the solution diluted before to be injected in HPLC/UV Shimadzu, SCL-10 AVP (Primera Analytical Solutions Corp., Princeton, NJ, USA).

The organic C in soil (SOC) was measured before the organic fertiliser distribution (on April $23^{\text {rd }}, 2013$ ) and after a year of cultivation on April 24 $4^{\text {th }}, 2014$. In the first case, 5 sub-samples per each of the three replicates analysed, were picked up in the soil profile $0-30 \mathrm{~cm}$ of the whole experimental area. In the second case, in each experimental plots, a sample was picked up by mixing three sub-samples. SOC content was determined by Walkley-Black method.

\section{Statistical analysis}

Data about fresh and dry biomass as well as data about nitrate contents in leaves of rocket were analysed with one way analysis of variance (ANOVA) where the treatment organic improver $x$ dose was the fixed factor. Means were separated by orthogonal contrasts, adopting a predefined set of eight contrasts defined as follows: i) amendants $\mathrm{vs}$ Cnt: all the treatments with organic amendants compared to the control; ii) dose $15 v s$ dose 30: the average effects of all the amendants applied at dose $15 \mathrm{t}$ against dose $30 \mathrm{t}$; iii) all Com dose 15 vs BM 15: the average effect of all the composts against the buffalo manure when applied at dose $15 \mathrm{t}$; iv) BWCom 15 vs OPCom 15: in order to separate the effect of different composts, we compared the Biowaste compost at dose $15 \mathrm{t}$ against the average effect of the two olive pomace composts at the same dose; v) OPComL 15 vs OPComH 15: in order to assess the effect of different $\mathrm{C} / \mathrm{N}$ ratio in the two olive pomace composts applied at dose $15 \mathrm{t}$; vi) All Com dose 30 vs BM 30: the average effect of all the composts against the cow manure when applied at dose $30 \mathrm{t}$; vii) BWCom 30 vs OPCom 30: in order to separate the effect of different composts, we compared the Biowaste compost at dose $30 \mathrm{t}$ against the average effect of the two olive pomace composts at the same dose; viii) OPComL 30 vs OPComH 30: in order to assess the effect of different $\mathrm{C} / \mathrm{N}$ ratio in the two olive pomace composts applied at dose $30 \mathrm{t}$.

Data on soil organic $\mathrm{C}$ were analysed by one way ANOVA and the means separated, if appropriate, by Tukey test at $\mathrm{P}=0.05$.

\section{Results}

In Table 4, the marketable yields of the baby leaf crops practiced in the whole year are shown in a synoptic form. The first cycle of rocket, carried out from May to June 2013, followed the composts and manure distribution to soil. The mean separation through the orthogonal contrasts pointed out no significant difference between the $\mathrm{Cnt}$ and the mean yield from all organic improvers. Both the doses of buffalo manure determined the higher yields as f.w. and dry weight (d.w.) than the composts. In average, all the organic improvers sustained higher fresh and dry matter yields with the dose $15 \mathrm{t}$ compared to the dose $30 \mathrm{t}$. Among the composts, different behaviours to the increasing dose applied were observed. Indeed, applying $15 \mathrm{t} \mathrm{ha}^{-1}$ the yields varied from $44.7 \mathrm{tha}^{-1}$ of BWCom to 38.7 of OPComH without significant differences, while when the doses of composts increased to $30 \mathrm{t} \mathrm{ha}^{-1}$, the yields dramatically lowered putting in evidence a more detrimental effect of OPCom respect to BWCom. The mean dry matter content of rocket leaves was $6.2 \%$.

Table 4. Fresh and dry weight biomass produced by rocket and basil in the three cycle monitored along the year. Mean separation through orthogonal contrasts.

\begin{tabular}{|c|c|c|c|c|c|c|}
\hline \multirow[b]{2}{*}{ Organic amendants } & \multicolumn{2}{|c|}{ Rocket (cycle May-June 2013) } & \multicolumn{2}{|c|}{ Basil (cycle Aug-Oct 2013) } & \multicolumn{2}{|c|}{ Rocket (cycle Nov '13-May '14) } \\
\hline & $\begin{array}{l}\text { Fresh weight } \\
\qquad\left(\mathrm{th} \mathrm{a}^{-1}\right)\end{array}$ & $\begin{array}{l}\text { Dry weight } \\
\left(\mathrm{t} \mathrm{ha}^{-1}\right)\end{array}$ & 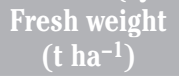 & 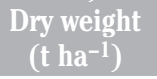 & $\begin{array}{l}\text { Fresh weight } \\
(\mathrm{t} \mathrm{ha-1)}\end{array}$ & $\begin{array}{l}\text { Dry weight } \\
\left(\mathrm{tha}^{-1}\right)\end{array}$ \\
\hline BWCom 15 & 44.7 & 2.9 & 18.6 & 1.9 & 75 & 4.6 \\
\hline BWCom 30 & 30.7 & 1.5 & 17.7 & 1.6 & 80.8 & 4.6 \\
\hline OPComL 15 & 40.9 & 2.5 & 18.4 & 1.7 & 69.6 & 4.0 \\
\hline OPComL 30 & 23.6 & 1.4 & 12.7 & 1.3 & 72.1 & 4.1 \\
\hline OPComH 15 & 38.7 & 2.4 & 22.2 & 1.9 & 70.5 & 4.1 \\
\hline OPComH 30 & 20.1 & 1.4 & 14.6 & 1.5 & 78.5 & 4.3 \\
\hline BM 15 & 53.1 & 3.3 & 19.1 & 1.8 & 70 & 4.5 \\
\hline BM 30 & 50.7 & 3.0 & 16.9 & 1.7 & 77 & 4.5 \\
\hline Cnt & 37.2 & 2.5 & 14.6 & 1.5 & 71.4 & 4.0 \\
\hline \multicolumn{7}{|l|}{ Orthogonal contrasts } \\
\hline Amendants vs Cnt & n.s. & n.s. & n.s. & n.s. & n.s. & $3.2^{* * *}$ \\
\hline Dose 15 vs Dose 30 & $13.1^{* * *}$ & $0.99 * * *$ & $4.1^{* * *}$ & $0.32^{* * *}$ & $-5.8^{* * *}$ & n.s. \\
\hline All Com dose 15 us BM 15 & $-11.7^{* * *}$ & $-0.71^{* * *}$ & n.s. & n.s. & n.s. & $-0.2^{*}$ \\
\hline BWCom 15 us OPCom 15 & n.s. & $0.47^{* *}$ & n.s. & n.s. & n.s. & $0.57^{* * *}$ \\
\hline OPComL 15 us OPComH 15 & n.s. & n.s. & n.s. & n.s. & n.s. & n.s. \\
\hline All Com dose 30 us BM 30 & $-25.4^{* * *}$ & $-1.58^{* * *}$ & n.s. & n.s. & n.s. & n.s. \\
\hline BWCom 30 us OPCom 30 & $8.8^{* *}$ & n.s. & $4.1^{*}$ & n.s. & $5.5^{*}$ & $0.44^{* * *}$ \\
\hline OPComL 30 us OPComH 30 & n.s. & n.s. & n.s. & n.s. & $-6.4^{*}$ & n.s. \\
\hline
\end{tabular}

The positive or negative values on the left of asterisks indicate the difference between the first $(+)$ or the second (-) mean of the two contrasted groups; * **, *** indicate the significant levels of the contrasts, respectively $\mathrm{P}=0.05 ; \mathrm{P}=0.01 ; \mathrm{P}<0.001 ;$ n.s., not significant difference. BWCom, municipal source separated organic fraction compost; OPComL, olive pomace compost with low carbon/nitrogen (C/N) ratio; $\mathrm{OPComH}$, olive pomace compost with high C/N; BM, buffalo manure; Cnt, control; 15 and 30 are the rates of compost on fresh weight basis. 
The basil crop cycle carried out from August to October 2013 did not evidence significant differences among all the treatments whose mean yields, in terms of f.w. and d.w., were $17.2 \mathrm{t} \mathrm{ha}^{-1}$ and $1.6 \mathrm{ha}^{-1}$, respectively. The only significant effect was the persistence of a productivity advantage with the lower dose of application, although with very low margins compared to that observed in rocket. The mean dry matter content of basil leaves was $9.7 \%$.

The last cycle of rocket was the longer one, going through the winter until the spring.

The mean yield was about $73 \mathrm{t} \mathrm{ha}^{-1}$ double of the mean yield of the preceding spring-summer cycle. Dry matter content of leaves was $5.8 \%$. No significant fresh weight production difference was detected between $\mathrm{Cnt}$ and, in average, all the organic improvers. On the contrary, dry matter production in amended treatments was significantly higher than Cnt. Higher yields were harvested, in average, with the dose $30 \mathrm{t}$ with respect to the dose $15 \mathrm{t}$. No difference was detected between manure and the different composts tested. However, $\mathrm{OPCom}_{\mathrm{s}}$, particularly that one with low $\mathrm{C} / \mathrm{N}$, showed again a reduction of productivity at the higher dose when compared to BWCom.

As showed in Figure 1 regarding the first rocket cycle, the detected concentrations of nitrates in the leaves of rocket were variable with date of harvest. Nevertheless, in the cut of June $11^{\text {th }}, 2013$, the limits went beyond in leaves from BWCom 15, BM 15, Cnt. It is worth to note that the most part of the measured nitrate concentrations in all $\mathrm{OPCom}_{\mathrm{s}}$ and BWCom 30 did not exceeded $4000 \mathrm{mg} \mathrm{kg}^{-1}$ f.w.. The first part of Table 5 , displayed the mean values of nitrate concentrations detected in the three harvests. The orthogonal contrasts confirmed that: i) the higher concentrations were obtained with BM at both the doses; ii) dose $15 \mathrm{t}$ accumulated more nitrates than dose $30 \mathrm{t}$; ii) $\mathrm{OPCom}_{\mathrm{s}} 15$ showed lower nitrate contents than BWCom; in particular, OPComH favoured a reduction of nitrates more than OPComL.
As it is shown in Figure 2, regarding the second rocket cycle, either BWCom 15 and 30 or BM 15 and 30 went beyond the limit in the harvest of March $28^{\text {th }}$. The second part of the Table 5 permitted to state that the dose 15 of organic improvers favoured a higher nitrate concentration than the dose 30 . Besides, BM 15 determined a significant higher content than the average of composts but, among them, rocket leaves grown in BWCom 15 had more nitrates than the two olive pomace composts. After a year from composts and manure distribution, four crop cycles and as many soil tillage, the measure of SOC gave the information showed in Figure 3. Taking into account the baseline level of SOC measured before organic matter application ( $\left.5.3 \mathrm{~g} \mathrm{~kg}^{-1} \mathrm{soil}\right)$, it was evident that in Cnt, the SOC content of $5.9 \mathrm{~g} \mathrm{~kg}^{-1}$ represented a range of variation not ascribable to the only burying of crop residues but to soil heterogeneity/laboratory approximations. Therefore, being evident that SOC content measured in amended plots did not differ from Cnt, despite of large amounts of organic $C$ inputted with compost and manure (Table 2), we can suppose that the most part of it was mineralised.

\section{Discussion}

The choice to distribute the different quantities of organic improvers as fresh matter responded to the need of adopting a simple approach to perform in the farm. As a consequence, the contents of dry matter, organic carbon or total nitrogen supplied, particularly between the composts and manure, were not always comparable (Table 2). We have to take in mind this aspect in the discussion of our data. The production of fresh or dry biomass of the whole crop sequence in Cnt treatment, reached amounts only slightly lower than fertilised treatments.

Table 5. Nitrate concentration in leaves of rocket picked up in the first and the second cycle as influenced by different treatments.

\begin{tabular}{|c|c|c|}
\hline Organic amendants & $\begin{array}{l}\text { Rocket (cycle May-June 2013) } \\
\text { (mg kg-1 fresh matter) }\end{array}$ & $\begin{array}{l}\text { Rocket (cycle Nov '13-May '14) } \\
\text { (mg kg }{ }^{-1} \text { fresh matter) }\end{array}$ \\
\hline BWCom 15 & 5272 & 6694 \\
\hline BWCom 30 & 2943 & 6331 \\
\hline OPComL 15 & 3284 & 5825 \\
\hline OPComL 30 & 3354 & 5861 \\
\hline OPComH 15 & 4503 & 5824 \\
\hline OPComH 30 & 3142 & 5491 \\
\hline BM 15 & 5874 & 7008 \\
\hline BM 30 & 3738 & 5958 \\
\hline Cnt & 4417 & 5706 \\
\hline Average & 4059 & 6078 \\
\hline \multicolumn{3}{|l|}{ Orthogonal contrasts } \\
\hline Amendants vs Cnt & n.s. & n.s. \\
\hline Dose 15 vs Dose 30 & $1439 * * *$ & $427^{*}$ \\
\hline All Com dose 15 vs BM 15 & $-1521 * * *$ & $-893^{* *}$ \\
\hline BWCom 15 us OPCom 15 & $1378^{* * *}$ & $870^{*}$ \\
\hline OPComL 15 vs OPComH 15 & $-1219 * * *$ & n.s. \\
\hline All Com dose 30 us BM 30 & $-592^{*}$ & n.s. \\
\hline BWCom 30 vs OPCom 30 & n.s. & n.s. \\
\hline OPComL 30 us OPComH 30 & 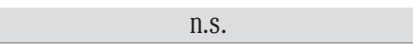 & 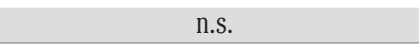 \\
\hline
\end{tabular}


Cnt was supplied with a low amount of $\mathrm{N}$ fertilisers, so its productivity was mainly sustained by $\mathrm{N}$ mineralised in soil where $\mathrm{C} / \mathrm{N}$ ratio $(=8.7)$ indicated a prevalence towards mineralisation. In this frame, BM treatment supplied a good amount of easily available $\mathrm{N}$ as revealed in the first cycle of rocket when yield was about $40 \%$ higher than Cnt. On the contrary, the first cycle of rocket pointed out a growing competition for nitrogen between soil microorganisms and roots triggered by the application of compost. The incubation studies of $\mathrm{N}$ and $\mathrm{C}$ mineralisation of different manures and composts in pots, carried out by Hartz et al. (2000), evidenced a faster organic $\mathrm{N}$ mineralisation rate of $15-16 \%$ in manure compared to $1-2 \%$ of plant residues compost in 12-16 weeks of incubation, respectively. Besides, as discussed in Morra et al. (2013), the kind of compost (olive pomace $>$ biowaste compost) and the applied dose $\left(20 \mathrm{t} \mathrm{ha}^{-1}\right.$ d.w. $>10 \mathrm{t} \mathrm{ha}^{-1}$ d.w.) can stress this competition that cause an initial decrease of vegetables yields. In particular, the olive pomace compost, regardless of its $\mathrm{C} / \mathrm{N}$ ratio, confirmed to immobilise nitrogen during its decomposition in the short-term (3-12 months) as stated by Garcia-Ruiz (2012). In agree to this statement is the observation that from 6 to 12 months after the amendment, the second cycle of rocket pointed out an alignment of yields among different treatments. Besides, the yields at the dose $30 \mathrm{t}$ were higher than the dose $15 \mathrm{t}$, due to the increased $\mathrm{N}$ availability from a high initial total amount.

With regard to the nitrates concentration detected in leaves of rocket, it resulted as an indicator consistent with time and amount of $\mathrm{N}$ available from different amendments as previously discussed. Apart the variability of the measured contents, a significant trend can be depicted: the dose $15 \mathrm{t} \mathrm{ha}^{-1}$ of fertilisation determined nitrate amounts higher than the dose 30; above all, rocket grown on BM treated plots exceeded the fixed thresholds either in one harvest of summer cycle or in another one of winter cycle, while, in compost treated plots, particularly those ones treated with OPCom, the nitrate level was often within the limits of EU Regulation 1258/2011 (European Commission, 2011). Cavaiuolo and Ferrante (2014) reported in their review that organic grown rocket usually has higher nitrate content in leaves compared to the conventional ones. Indeed, the mineralisation of the organic matter releases the mineral nutrients to satisfy the plant requirements, but during spring and summer, the high temperatures accelerate the mineralisation with release of nutrients including high amounts of nitrates. In the environmental conditions of our experiment located under tunnel, did not seem to be realised these extremes especially with composts.

No significant change of the initial soil organic carbon content was attributable to the different organic improvers and to their doses of application after one year from the distribution. However, considering the higher amounts of carbon supplied with BWCom and OPCom compared to $\mathrm{BM}$ (Table 2), a high rate of $\mathrm{C}$ mineralisation could have been promoted by the large $\mathrm{C}$ amounts available and the favourable thermohygrometric conditions in soil under tunnel. This statement is more evident taking in account the SOC level variation in the Cnt not fertilised. Not even the different $\mathrm{C} / \mathrm{N}$ ratio of the two olive pomace composts modified the fate of organic carbon applied. Scotti et al. (2012) in a study carried out for two years under tunnel in Sele river Plain, applied two doses of biowaste compost ( 30 and $60 \mathrm{t} \mathrm{ha}^{-1}$ f.m.) characterised by two $\mathrm{C} / \mathrm{N}$ ratio (15 and 25) obtained by mixing compost with wood chips. The authors observed the same significant increases of SOC with both the doses and independently from $\mathrm{C} / \mathrm{N}$ ratio of composts applied. This latter result is in agreement with our current observations while the former one is not in agreement with our current results. A key-lecture could be represented by the number of crop cycle performed: 4 in a year in our experiment, 5 in two years in the Scotti's experiment. Therefore, as could be expected (Balesdent et al., 2000), the high frequency of soil tillage in a baby leaf crops sequence has appeared difficult to adjust with a recovery of organic matter in degraded soils.

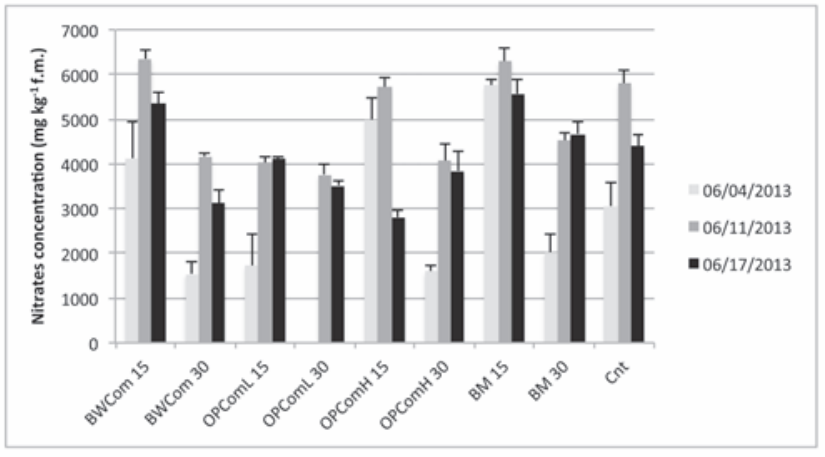

Figure 1. Nitrates concentration measured in the leaves harvested in three cuts of the first cycle of rocket in 2013 as influenced by the different fertilisation treatments. BWCom, municipal source separated organic fraction compost; OPComL, olive pomace compost with low carbon/nitrogen ratio; OPComH, olive pomace compost with high $\mathrm{C} / \mathrm{N}$; $\mathrm{BM}$, buffalo manure; Cnt, control; 15 and 30 are the rates of compost on fresh weight basis. Vertical bars represent the standard error of the means.

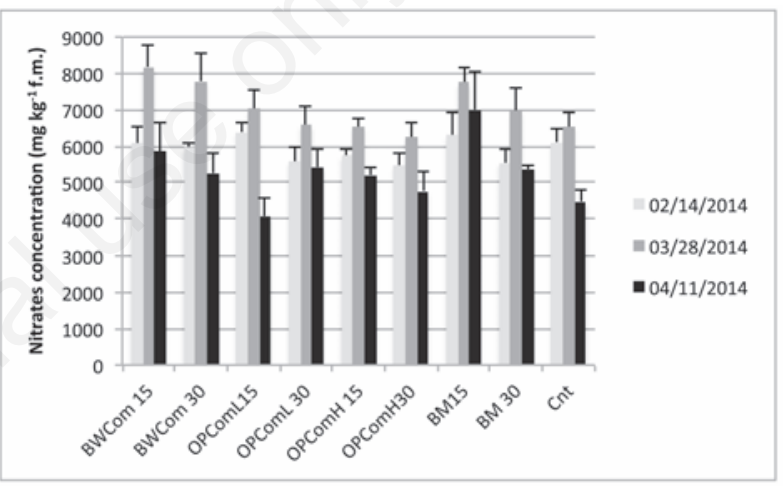

Figure 2. Nitrates concentration measured in the leaves harvested in three cuts of the second cycle of rocket in 2014 as influenced by the different fertilisation treatments. BWCom, municipal source separated organic fraction compost; OPComL, olive pomace compost with low $\mathrm{C} / \mathrm{N}$; OPComH, olive pomace compost with high $\mathrm{C} / \mathrm{N}$; BM, buffalo manure; Cnt, control; 15 and 30 are the rates of compost on fresh weight basis. Vertical bars represent the standard error of the means.

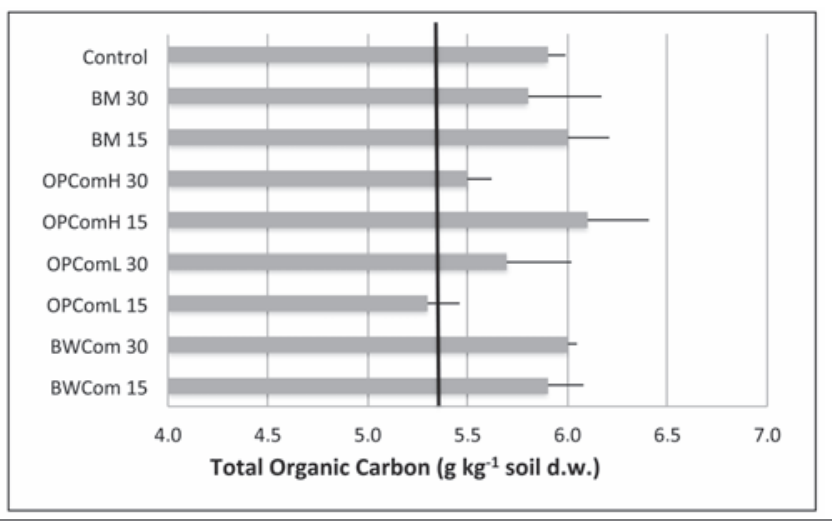

Figure 3. Soil organic carbon (C) contents as influenced by different fertilisation treatments measured after one year from their application to soil. The black vertical line represents the soil organic C content at the start of experiment on May 2013; not significant difference were found among the mean of different treatments. 


\section{Conclusions}

The supply of high amounts (until to $8.5 \mathrm{tha}^{-1}$ ) of organic $\mathrm{C}$ through composts or manure did not balance the high $\mathrm{C}$ mineralisation rate triggered by the interaction of the repeated soil tillage and the thermohygrometric conditions under tunnel, favourable to continuous soil microbial activity. So, after only a year of observations, it appears difficult to match a program of recovery of soil organic matter content to a farm productive scheduling highly intensive. The safeguard of soil, a not renewable primary resource, cultivated to leafy vegetable crops, requires a re-thinking of the soil tillage management under tunnel.

From a nutrients availability point of view, the composts as well as the buffalo manure sustained the annual crop sequence. However, it has to be avoided the supply of large amounts of total $\mathrm{N}$, as in the case of $\mathrm{OPComH}$, dangerous for the pollution of groundwaters.

Nitrates accumulation in the leaves of rocket, instead, was increased, in particular, by cow manure. Probably, this was due to the major quickness in releasing nitrogen forms available to be absorbed from plants. The composts, specially the olive pomace compost, often reduced the uptake of nitrates in leaves. Composting plays an important role in enhancing the availability of nutrients essential to plant growth and reducing the presence of human pathogens in amendments. Thus organic wastes properly composted such as urban solid waste can be considered a suitable alternative to other soil amendments for the production of baby leaves such as rocket (Selma et al., 2010). However, from a nitrogen utilisation efficiency point of view, at the tested amendment rates, the obtaining a substantial increase in soil N supply would require a long-term program of repeated application. It is foreseen, in the second year of the experiment, the assessment of an $\mathrm{N}$ balance sheet in order to better estimate the supply of nitrogen by organic improvers in absence of $\mathrm{N}$ mineral fertilisers.

\section{References}

Balesdent J, Chenu C, Balabane M, 2000. Relationship of soil organic matter dynamics to physical protection and tillage. Soil Till. Res. 53:215-30.

Bonanomi G, D’Ascoli R, Antignani V, Capodilupo M, Cozzolino L, Marzaioli R, Puopolo G, Rutigliano F A, Scelza R, Scotti R, Rao M A, Zoina A, 2011. Assessing soil quality under intensive cultivation and tree orchards in Southern Italy. Appl. Soil Ecol. 47:184-94.

Bronick CJ, Lal R, 2005. Soil structure and management: a review. Geoderma 124:3-22.

Buckwell A, Uhre AN, Williams A, Polakova J, Blum WEH, Schiefer J, Lair GJ, Heissenhuber A, Sciebl P, Kramer C, Haber W, 2014. Sustainable intensification of European agriculture. A review sponsored by the RISE Foundation. Available from: www.ieep.eu/assets/1404/ 111120_BROCH_SUST_INTENS_DEF.pdf

Cavaiuolo M, Ferrante A, 2014. Nitrates and glucosinolates as strong determinants of the nutritional quality in rocket leafy salads. Nutrients 6:1519-38.

European Commission, 2006. Commission Regulation (EC) No
1882/2006 of 19 December 2006 laying down methods of sampling and analysis for the official control of the levels of nitrates incertain foodstuffs. In: Official Journal, L 364, 20/12/2006, pp 25-31.

European Commission, 2011. Regulation (EC) No 1258/2011 amending Regulation (EC) No. 1881/2006 as regards maximum levels for nitrates in foodstuffs. In: Official Journal, L 320, 3/12/2011, pp 15-17.

Fontana E, Tibaldi G, Nicola S, 2010. Passato e future della ricerca per gli ortaggi di IV gamma. Italus Hortus 17:28-31.

Franceschini A, 2014. IV gamma: vendite in calo, ma il fermento continua. Inf. Agrario 19:33-5.

Garcia-Ruiz R, Ochoa MV, Hinojosa MB, Gomez-Munoz B, 2012. Improved soil quality after 16 years of olive mill pomace application in olive oil groves. Agron. Sustain. Dev. 32:803-10.

Hartz TK, Mitchell JP, Giannini C, 2000. Nitrogen and carbon mineralization dynamics of manures and composts. HortSci. 35:209-12.

Martinetti L, 1996. Contenuto di nitrati e nitriti in lattuga (Lactuca sativa) al variare della concimazione azotata. Riv. Agron. 1:92-6.

Morra L, Pizzolongo G, Baiano S, Pentangelo A, 2013. Comparison of olive pomace and biowaste composts in a vegetable cropping system. Ital. J. Agron. 8:206-16.

Nicola S, Fontana E, 2007. Cultivation management on the farm influences postharvest quality and safety. Acta Hort. 746:273-80.

Paradiso R, De Pascale S, Barbieri G, 2001. Effetto del regime irriguo e delle dosi di azoto su consume idrici, resa e contenuto di nitrati in spinacio. Italus Hortus 4:14-21.

Parente A, Santamaria P, Serio F, Conversa G, L'Abbate P, Bianco VV, 2002. Concimazione azotata, cultivar e produzione di lattuga. Colture Protette 12:28-32.

Penati M, Ferrante A, Martinetti L, Quattrini E, Marino P., Schiavi M., Falavigna A, Salamone F, Sari M, Frigeni S, Rocchetti R, Facchetti M, 2009. Asportazioni di elementi nutritive ed ottimizzazione della fertilizzazione delle colture da foglia destinate alla IV gamma. Quaderni della Ricerca no. 107 - Dicembre 2009. Regione Lombardia, Milano, Italy. Available from: http://www.agricoltura.regione.lombardia.it/shared/ccurl/429/246/Qdr\%20n.\%2010 7-\%202010.pdf

Pimpini F, Giannini M, Lazzarin R, 2005. Ortaggi da foglia da taglio. Veneto Agricoltura Publ., Legnaro (PD), Italy.

Santamaria P, 2006. Nitrate in vegetables: toxicity, content, intake and EC regulation. J. Sci. Food Agric. 86:10-7.

Santamaria P, Elia A, Serio F, 2002. Effect of solution nitrogen concentration on yield, leaf element content and water and nitrogen use efficiency of three hydroponically-grown rocket salad genotypes. J Plant Nutr 2:245-58.

Scotti R, Sultana S, Gonzalez Caceres M, Marzaioli R, Scelza R, Cozzolino L, Bonanomi G, D’Ascoli R, Rao M A, Zoina A, 2012. L'utilizzo di compost a differente rapporto $\mathrm{C} / \mathrm{N}$ in coltura protetta. Italus Hortus 5:65-70.

Selma MV, Martinez-Sanchez A, Allende A, Ros M, Hernandez MT, Gil MI, 2010. Impact of organic soil amendments on phytochemicals and microbial quality of rocket leaves (Eruca sativa). J. Agric. Food Chem. 58:8331-7.

Suslow TV, Oria MP, Beuchat LR, Garrett EH, Parish ME, Harris LJ, Farber JM, Busta FF, 2003. Production practices as risk factors in microbial food safety of fresh and fresh-cut produce. Compr. Rev. Food Sci. Food Saf. 2:38-77. 